\title{
Influences of Silica Fume on Compressive Strength and Chemical Resistances of High Calcium Fly Ash-Based Alkali-Activated Mortar
}

\author{
Kantiya Sothornchaiwit ${ }^{1}$, Warayut Dokduea ${ }^{1}$, Weerachart Tangchirapat ${ }^{1, * \mathbb{D}}$, Suraparb Keawsawasvong ${ }^{2}{ }^{\mathbb{D}}$, \\ Chanachai Thongchom ${ }^{2}$ (D) and Chai Jaturapitakkul ${ }^{1}$
}

1 Construction Innovations and Future Infrastructures Research Center (CIFIR), Department of Civil Engineering, Faculty of Engineering, King Mongkut's University of Technology Thonburi, Bangkok 10140, Thailand; so.kantiya@gmail.com (K.S.); naiwarayut@gmail.com (W.D.); chai.jat@kmutt.ac.th (C.J.)

2 Department of Civil Engineering, Faculty of Engineering, Thammasat School of Engineering, Thammasat University, Pathumthani 12120, Thailand; ksurapar@engr.tu.ac.th (S.K.); tchanach@engr.tu.ac.th (C.T.)

* Correspondence: weerachart.tan@kmutt.ac.th

Citation: Sothornchaiwit, K.; Dokduea, W.; Tangchirapat, W.;

Keawsawasvong, S.; Thongchom, C.; Jaturapitakkul, C. Influences of Silica Fume on Compressive Strength and Chemical Resistances of High Calcium Fly Ash-Based AlkaliActivated Mortar. Sustainability 2022, 14, 2652. https://doi.org/10.3390/ su14052652

Academic Editors: Quoc Tri Phung and Nguyen Van Tuan

Received: 31 January 2022

Accepted: 16 February 2022

Published: 24 February 2022

Publisher's Note: MDPI stays neutral with regard to jurisdictional claims in published maps and institutional affiliations.

Copyright: (C) 2022 by the authors. Licensee MDPI, Basel, Switzerland. This article is an open access article distributed under the terms and conditions of the Creative Commons Attribution (CC BY) license (https:// creativecommons.org/licenses/by/ $4.0 /)$.

\begin{abstract}
Although elevated temperature curing can increase the compressive strength of alkaliactivated mortar, its field applications are still limited. In this study, alkali-activated mortars were prepared using high calcium fly ash (FA) as a precursor. Small amounts of silica fume were used to partially replace high calcium fly ash at 3-9\% by weight to increase the strength of alkali-activated mortar. All mixtures had a liquid to binder ratio of 0.60 and sand to binder ratio of 2.75 by weight. A ratio of $\mathrm{NaOH}$ to $\mathrm{Na}_{2} \mathrm{SiO}_{3}$ solution was kept at 2:1 by weight. Mortar flow was also held between 105-115 using a superplasticizer. Compressive strength and durability were investigated in terms of acid and sulfate resistance. The effects of silica fume addition and curing temperature on compressive strength were found to be significant. The optimum content of silica fume was $6 \%$, providing compressive strength as high as that of alkali-activated mortars cured at $45{ }^{\circ} \mathrm{C}$. The weight loss of alkali-activated mortar due to sulfuric acid attack decreased with increasing silica fume content and curing temperature. All alkali-activated mortars were found to have a better performance than (ordinary) Portland cement (OPC) mortars and mortars containing 40\% FA. Alkali-activated mortars immersed in magnesium sulfate solutions had compressive strength that decreased with an increase in curing temperature. The expansion of alkali-activated mortar due to sodium sulfate attack increased with increasing silica fume content, and the expansion decreased with increased curing temperature. All alkali-activated mortars performed better than OPC mortars after 98 days of sulfate attack.
\end{abstract}

Keywords: alkali activated mortar; silica fume; magnesium sulfate; sodium sulfate; sulfuric acid

\section{Introduction}

Each ton of cement produced today results in approximately $0.35-0.55$ tons of carbon dioxide emission [1]. Supplementary cementitious materials (e.g., fly ash, silica fume, blast-furnace slag, metakaolin, and biomass ash) are used to reduce Portland cement consumption by replacing it in concrete [2-4]. Recycled waste glass powder has also been used to partially replace cement in concrete partially replaced by fly ash [5-7]. However, Portland cement is still the primary binder used to produce mortar and concrete.

Alkali-activated materials are an environmentally friendly, well-known, and conventional alternative to cementitious materials as cement binders. In addition, alkali-activated mortar can be made by the reaction of an alkali solution with pozzolanic materials containing high silica and alumina components (e.g., fly ash, silica fume, and rice husk ash) [8-10]. 
However, the initial strength of alkali-activated materials is quite low. Previous studies have reported that these materials maintain greater strength after exposure to high temperatures [11-15]. Nevertheless, it is difficult to cure these materials at high temperatures in real construction projects. The use of silica fume to enhance the initial strength of alkali-activated materials is one of the efficient replacements to partially replace fly ash for promoting the strength of mortar [16,17].

According to earlier studies [18-21], (ordinary) Portland cement (OPC) and blended cement concretes exposed to external sulfate attack in the environment generally deteriorate because of reactions between sulfate-bearing solutions and cement hydration products. These reactions cause calcium-silicate-hydrate $(\mathrm{C}-\mathrm{S}-\mathrm{H})$ destruction and the formation of gypsum and ettringite, resulting in expansion and cracking on concrete surfaces [22-25]. Several previous works have shown that alkali-activated mortars have various outstanding properties. Compared to Portland cement concrete, alkali-activated mortars have better resistance against acid and sulfate attacks [26-29].

Van Jaarsveld et al. [30] and Davidovits [31] found that alkali-activated cement with metakaolin (MK) immersed in 5\% by weight sulfuric acid solution for 4 weeks led to low mass loss. The strength of alkali-activated mortar materials based on fly ash after immersion in $5 \%$ by weight acetic and sulfuric acid solutions was studied by Bakharev [32]. This work found that the alkali-activated mortar materials based on fly ash have superior strength to those based on Portland cement. The resistances of alkali-activated mortars made from bottom ash immersed in 5\% sodium sulfate and 3\% sulfuric acid solutions were investigated by Sata et al. [33]. They found that these mortars had a lower mass loss and higher compressive strength than Portland cement mortars after 120 days of immersion.

An investigation on the durability of blended geopolymer concrete based on fly ash and palm oil fuel ash was carried out by Ariffin et al. [34], who recorded the mass loss and compressive strength after 18 months of exposure to a $2 \%$ solution of sulfuric acid. This work found that the performance of geopolymer concretes exposed to a $2 \%$ sulfuric acid solution for more than a year were superior to OPC concretes that are attributed to a more stable cross-linked aluminosilicate polymer structure formed in the geopolymer concrete. Duan et al. [35] studied the microstructure and durability of alkali-activated mortars made from a fluidized bed of fly ash-metakaolin. They reported compressive strength and weight loss data for this alkali-activated mortar type after immersion in sulfuric and hydrochloric acid solutions. The compressive strength of OPCs showed a dramatic drop, while that of geopolymers showed an increase in strength after $400^{\circ} \mathrm{C}$. The mass loss of the geopolymer was similar to OPC, but it showed a lower mass loss.

The performance of alkali-activated mortars based on sugarcane bagasse ash and blast furnace slag after exposure to various kinds of acids was evaluated by Pereira et al. [36]. Mallikarjuna and Kireety [37] examined the performance of mortars made of fly ash and ground-granulated blast-furnace slag (GGBS) subjected to sulfuric and nitric acid solutions. $\mathrm{Li}$ and Peethamparan [38] investigated the deterioration of alkali-activated mortars made of fly ash and granulated blast furnace slag (GBFS) exposed to acetic acid. An experimental study on acid resistance of slag alkali-activated concrete modified with silica fume and fly ash was carried out by Elyamany et al. [39], considering compressive strength loss, weight loss, and absorption. In addition, other researchers studied fly ash alkali-activated mortars and concrete exposed to acetic and sulfuric acid over long periods [40-44].

This paper presents an investigation of the performance of alkali-activated mortars made of fly ash and fly ash mixed with silica fume as a binder. We examined the use of silica fume as a replacement for fly ash and the effect of curing at different temperatures (e.g., $45^{\circ} \mathrm{C}, 60^{\circ} \mathrm{C}$, and room temperature) on the compressive strength of these mortars. We then made measurements of several performance quantities after immersion of the alkali-activated mortars in various solutions. These measurements included compressive strength, mass loss due to attack from $3 \%$ by weight sulfuric acid resistance, compressive strength loss due to a $5 \%$ by weight magnesium sulfate attack, and expansion due to a $5 \%$ by weight sodium sulfate attack. If silica fume can enhance properties of alkali-activated 
mortars curing at ambient temperature or room temperature, it will reduce the limitation of the use alkali-activated mortars in the construction field. Moreover, it will be a good method to reduce energy for the curing of alkali-activated mortars and encourage the utilization of fly ash, a by-product from thermal power plants, in construction work, resulting in sustainable development.

\section{Materials and Methodology}

\subsection{Materials}

This study used fly ash (FA) from the Mae Moh power plant in northern Thailand as the primary precursor in an alkali-activated mortar. The effects of using silica fume (SF) to partially replace the fly ash to promote the strength of the mortar were also studied. The silica fume used in this study was a commercial product and obtained from company in Thailand. The specific gravity of FA and SF and the percent by weight of FA and SF retained in a No. 325 sieve are shown in Table 1. River sand passing a No. 30 sieve and retaining on a No. 100 sieve was used. Sodium silicate $\left(\mathrm{Na}_{2} \mathrm{SiO}_{3}\right)$ and sodium hydroxide $(\mathrm{NaOH})$ solutions were used as alkali activators, and superplasticizer (SP) was employed to obtain a specific mortar flow. The major chemical compositions of the binder materials, including FA and SF measured by X-ray fluoresce (XRF), are reported in Table 2.

Table 1. Physical properties of materials.

\begin{tabular}{ccc}
\hline Materials & Specific Gravity & Retained in a No. 325 Sieve (\%) \\
\hline Fly Ash & 2.26 & 28.70 \\
Silica Fume & 2.32 & 1.46 \\
\hline
\end{tabular}

Table 2. Chemical composition of the materials.

\begin{tabular}{|c|c|c|}
\hline Chemical Composition (\%) & Fly Ash & Silica Fume \\
\hline Silicon dioxide $\left(\mathrm{SiO}_{2}\right)$ & 27.9 & 98.2 \\
\hline Aluminum oxide $\left(\mathrm{Al}_{2} \mathrm{O}_{3}\right)$ & 14.4 & - \\
\hline Ferric oxide $\left(\mathrm{Fe}_{2} \mathrm{O}_{3}\right)$ & 15.6 & - \\
\hline Calcium oxide $(\mathrm{CaO})$ & 27.9 & - \\
\hline Magnesium oxide $(\mathrm{MgO})$ & 2.2 & 0.7 \\
\hline Sodium oxide $\left(\mathrm{Na}_{2} \mathrm{O}\right)$ & 1.9 & 0.5 \\
\hline Potassium oxide $\left(\mathrm{K}_{2} \mathrm{O}\right)$ & 2.8 & 0.6 \\
\hline Sulfur oxide $\left(\mathrm{SO}_{3}\right)$ & 7.1 & - \\
\hline Loss on ignition (LOI) & 0.2 & - \\
\hline
\end{tabular}

\subsection{Mix Proportions of Alkali-Activated Mortars}

The mix proportions of the alkali-activated mortar are tabulated in Table 3. All mixtures consisted of a liquid to binder ratio (L/B) of 0.60 and a sand to binder ratio (S/B) of 2.75 by weight. A ratio of $\mathrm{NaOH}$ to $\mathrm{Na}_{2} \mathrm{SiO}_{3}$ was controlled at 2:1 by weight. Mortar flow was maintained between $105 \%$ and $115 \%$ by using the superplasticizer (SP) to increase the flow rate of all mortar mixtures in this study. The amount of superplasticizer was determined in terms of percentage by weight of the binder weight. Two factors distinguished the alkali-activated mortar mixtures: the SF content in FA-based alkali-activated mortars $(0 \%$, $3 \%, 6 \%$, and $9 \%$ replacement by weight) and the curing temperature (room temperature (approximately $30^{\circ} \mathrm{C}$ ), $45^{\circ} \mathrm{C}$, and $60^{\circ} \mathrm{C}$ ). 
Table 3. Mix proportions of alkali-activated mortars.

\begin{tabular}{|c|c|c|c|c|c|c|c|}
\hline \multirow{2}{*}{ Sample } & \multicolumn{5}{|c|}{ Mix Proportion by Weight } & \multirow{2}{*}{ SP (\%) } & \multirow{2}{*}{ Flow $(\%$} \\
\hline & FA & SF & Sand & $\mathrm{NaOH}$ & $\mathrm{Na}_{2} \mathrm{SiO}_{3}$ & & \\
\hline 0SF30 & 100 & - & 275 & 40 & 20 & 6 & 108 \\
\hline 3SF30 & 97 & 3 & 275 & 40 & 20 & 7 & 110 \\
\hline 6SF30 & 94 & 6 & 275 & 40 & 20 & 8 & 113 \\
\hline 9SF30 & 91 & 9 & 275 & 40 & 20 & 9 & 114 \\
\hline OSF45 & 100 & - & 275 & 40 & 20 & 6 & 108 \\
\hline 0SF60 & 100 & - & 275 & 40 & 20 & 6 & 108 \\
\hline
\end{tabular}

The alkali-activated mortars used in this study were prepared by creating a solution of $\mathrm{NaOH}$ flakes dissolved in water for $24 \mathrm{~h}$ before being used. Next, $\mathrm{NaOH}$ and $\mathrm{Na}_{2} \mathrm{SiO}_{3}$ were mixed with powdered FA and SF as well as the SP for $30 \mathrm{~s}$. Then, river sand was gently poured into the mixture, and mixing occurred for an additional $30 \mathrm{~s}$. Later, the mixing speed was increased to a higher level for $30 \mathrm{~s}$ and paused for $90 \mathrm{~s}$, followed by mixing at a very high speed for the last $60 \mathrm{~s}$. The flowability of the mortar was determined by following the ASTM C230 standard [45] after the completion of the mixing.

\subsection{Testing Details}

\subsubsection{Compressive Strengths}

The mortar specimens were cast in $50 \mathrm{~mm} \times 50 \mathrm{~mm} \times 50 \mathrm{~mm}$ molds. After $24 \mathrm{~h}$ of casting, the specimen was de-molded and wrapped with a plastic sheet. Two curing approaches were used in this study. First, alkali-activated mortars were cured at room temperature until the testing date. SF was used to replace FA at rates of $0 \%, 3 \%, 6 \%$, and $9 \%$ by weight of the binder and denoted as 0SF30, 3SF30, 6SF30, and 9SF30, respectively. Second, after wrapping in plastic film, the mortars were cured at $45^{\circ} \mathrm{C}$ and $60^{\circ} \mathrm{C}$ in the oven for $24 \mathrm{~h}$ and then cured at room temperature until the testing date. These were denoted as 0SF45 and 0SF60, respectively. The compressive strength of the alkali-activated mortar samples was measured at 7, 28, 90, and 180 days using ASTM C109 [46]. The results of three specimens were averaged and presented for each testing age, with a maximum permissible range of $8.7 \%$. The total samples for investigating compressive strength were 72 samples.

\subsubsection{Sulfuric Acid Resistance}

In accordance with ASTM C267 [47], the sulfuric acid resistances of the mortars in Table 3 were determined using the $50 \mathrm{~mm} \times 50 \mathrm{~mm} \times 50 \mathrm{~mm}$ mortar specimens. The total of 72 mortar specimens were immersed in $3 \%$ sulfuric acid solution $(\mathrm{pH}=0.5)$ for 28 days after being cured in air. After the 28-day immersion in sulfuric acid, sample was softly brushed underwater by using a nylon brush, removing surface debris before weighing. Then, the percent weight loss of the samples was calculated by dividing the difference in weights before and after immersion by the initial weight before immersion. Note that the sulfuric acid solution concentration was checked and adjusted weekly.

\subsubsection{Sulfate Resistance}

The magnesium sulfate resistances of the alkali-activated mortars in Table 3 were determined by the immersion of $50 \mathrm{~mm} \times 50 \mathrm{~mm} \times 50 \mathrm{~mm}$ mortar specimens in a $5 \%$ by weight magnesium sulfate solution. The loss of compressive strength of these mortars was measured after an immersion time of 180 days, according to the ASTM C109 standard [46]. The reported result was obtained from the average of three samples, with a maximum permissible range of $8.7 \%$. The total samples were 18 samples.

Per ASTM C1012 [48], the durability of alkali-activated mortars attacked by sodium sulfate was investigated using mortar bars measuring $25 \mathrm{~mm} \times 25 \mathrm{~mm} \times 285 \mathrm{~mm}$ immersed 
in a $5 \%$ sodium sulfate solution for 98 days after curing. The expansions of the mortar bars after the immersions of 1-98 days were recorded to determine the expansion percentages. Three samples for each mortar type were determined, and the total samples were 18 samples. The sodium sulfate solution was replaced with a fresh solution every month.

\section{Results and Discussion}

\subsection{Compressive Strengths}

Figure 1 shows the compressive strength of the alkali-activated mortar containing FA without SF and cured at $30{ }^{\circ} \mathrm{C}$ (room temperature), $45^{\circ} \mathrm{C}$, and $60{ }^{\circ} \mathrm{C}$. Even though the long pre-curing at room temperature before applying heat strengthens all mortars, curing at elevated temperatures $\left(45^{\circ} \mathrm{C}\right.$ and $\left.60^{\circ} \mathrm{C}\right)$ for $24 \mathrm{~h}$ further increases their strength. The compressive strength increased with increasing curing time, particularly after 7 days. After 90 days, the rate of increase in strength became very low. The compressive strength was higher for the alkali-activated mortars cured at higher temperatures. This effect was because curing at a high temperature can significantly increase the initial strength of the alkali-activated mortar. During heat curing, the water expelled from the alkaliactivated mortar matrix can cause discontinuous nano-pores within the matrix, which directly improves its strength [13].

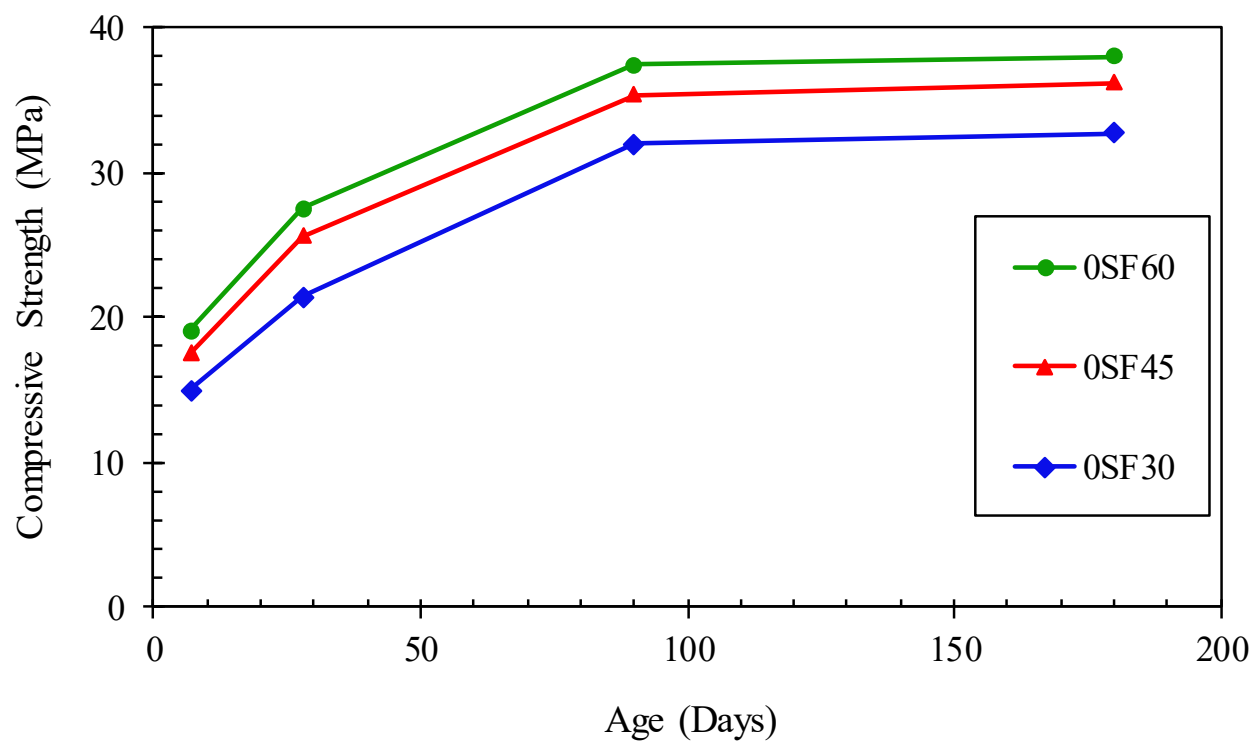

Figure 1. Relationships between compressive strength and age of the alkali-activated mortar curing at room temperature, $45^{\circ} \mathrm{C}$, and $60^{\circ} \mathrm{C}$.

At an optimum dosage of silica fume (SF) to partially replace FA, alkali-activated mortars will have an optimum improvement in their strengths under ambient curing $[13,49]$. In this study, the dosages of SF (3/6/9\%) for the mortars cured at $30{ }^{\circ} \mathrm{C}$ (room temperature) were selected to be compared with the cases of mortars curing at elevated temperatures $\left(45^{\circ} \mathrm{C}\right.$ and $60{ }^{\circ} \mathrm{C}$ ), as shown in Figure 2, in order to illustrate an appropriate dosage of SF and the efficiency of adding SF. Note that the case of the mortar with no SF cured at the room temperature (0SF30) is not shown in this figure, since we aimed to find an appropriate dosage of SF that could develop the compressive strength of mortars without being cured at elevated temperatures to be equally efficient as those cured at $45{ }^{\circ} \mathrm{C}(0 \mathrm{SF} 45)$ and $60{ }^{\circ} \mathrm{C}(0 \mathrm{SF} 60)$. From Figure 2, the mortar with $6 \%$ SF cured at room temperature (6SF30) had a compressive strength almost equal to the mortar without SF cured at $45{ }^{\circ} \mathrm{C}(0 \mathrm{SF} 45)$. The incorporation of 3\% SF did not improve the compressive strength as much as 6\% SF. In addition, the incorporation of $9 \%$ SF resulted in a significant decrease in compressive strength, to even less than the mortars without SF. However, the addition of SF could increase the workability (Flow\%), as seen in Table 3 [50]. It is evident that $6 \%$ SF can be 
employed to increase the compressive strength of alkali-activated mortar curing at room temperature as an alternative to curing at $45^{\circ} \mathrm{C}$.

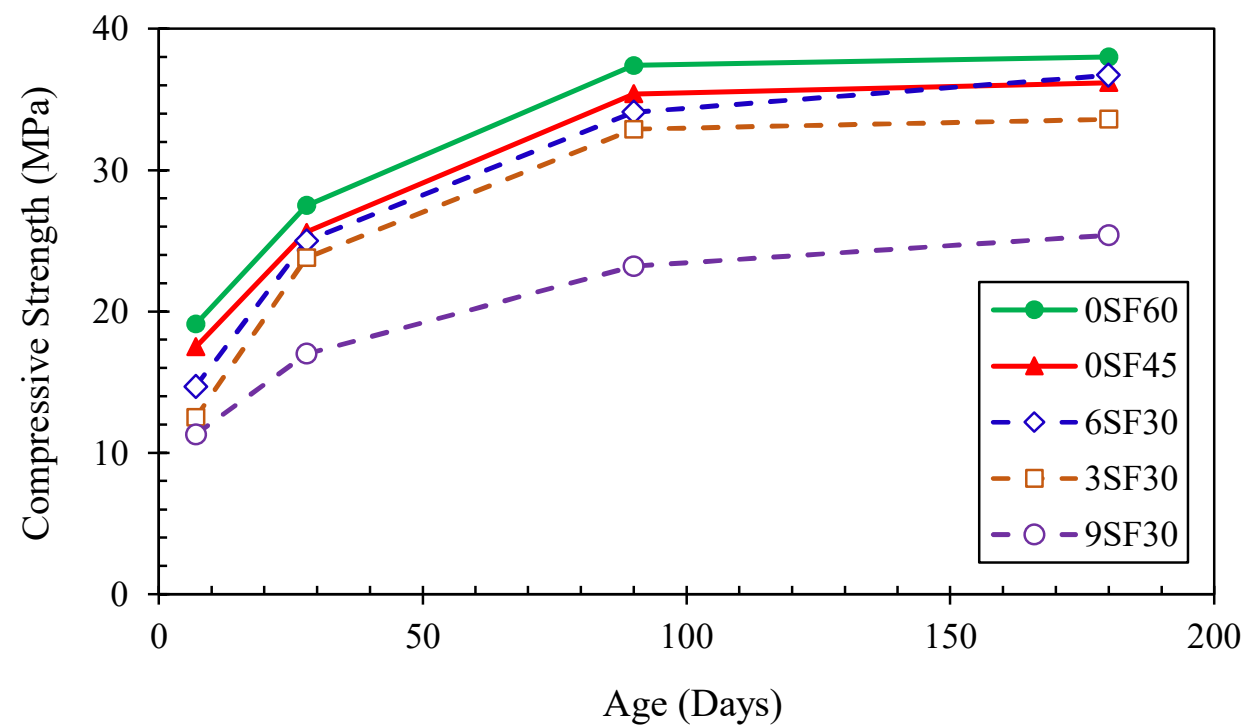

Figure 2. Relationships between compressive strength of the alkali-activated mortar and curing age.

\subsection{Resistance to Sulfuric Acid Attack}

Figure 3 shows the variation of the percentage weight loss due to sulfuric acid attack of mortars versus immersing time for the mortars cured at $30^{\circ} \mathrm{C}$ (room temperature), with different incorporations of $0 \%, 3 \%, 6 \%$, and $9 \%$ SF by weight to replace FA. Note that the results designated as "OPC" and "PFA40" in Figure 3 were obtained from the data of tested mortars made from pure Portland cement (OPC) and Portland cement replaced with FA at a dosage of $40 \%$ (PFA40) and immersed in 3\% sulfuric acid solution for 28 days. The results labeled "OPC" and "PFA40" were reported by Sata et al. [33]. Clearly, the percentage weight loss of the OPC and PFA40 concretes was extremely high compared to all of the alkaliactivated mortars in the present study. The action of acids on the OPC and PFA40 concretes was mainly caused by converting all calcium compounds (calcium hydroxide, calcium silicate hydrate, and calcium aluminate hydrate), which are unreacted residues of $\mathrm{C}_{3} \mathrm{~S}$ and $C_{2} S$ in cement grains, to the calcium salt. On the other hand, alkali-activated mortars experience some softening of surface when immersed in an acidic solution, which can significantly reduce the damage by acids. This softening of the surface layer is attributed to the low content of Ca compared to OPC and PFA40 concretes.

From Figure 3, for the cases of 0SF30, 3SF30, 6SF30, and 9SF30, an increase in the replacement of FA by SF resulted in an increase in sulfuric acid resistance, since a sample with a high SF ratio had a smaller weight loss than one with a lower SF ratio. The immersion time in the acid was 28 days. Note that the weight loss from the sulfuric acid attack was primarily due to the reaction between calcium (Ca) components in the sample and sulfuric acid, causing a scaling and cracking of the mortar. Therefore, the addition of SF, which mainly contained silica (Si) components, could reduce calcium components in a sample. These silica components also produced more $\mathrm{C}-\mathrm{S}-\mathrm{H}$ components to fill pore spaces in the alkali-activated mortars [33,51]. It is also seen in Figure 3 that, for the cases of the weight loss percentage of alkali-activated mortars without $\mathrm{SF}$ and cured at $30{ }^{\circ} \mathrm{C}$ (room temperature), $45^{\circ} \mathrm{C}$, and $60^{\circ} \mathrm{C}$, the resistance of alkali-activated mortars against $5 \%$ sulfuric acid solutions increased as the curing temperature increased. 


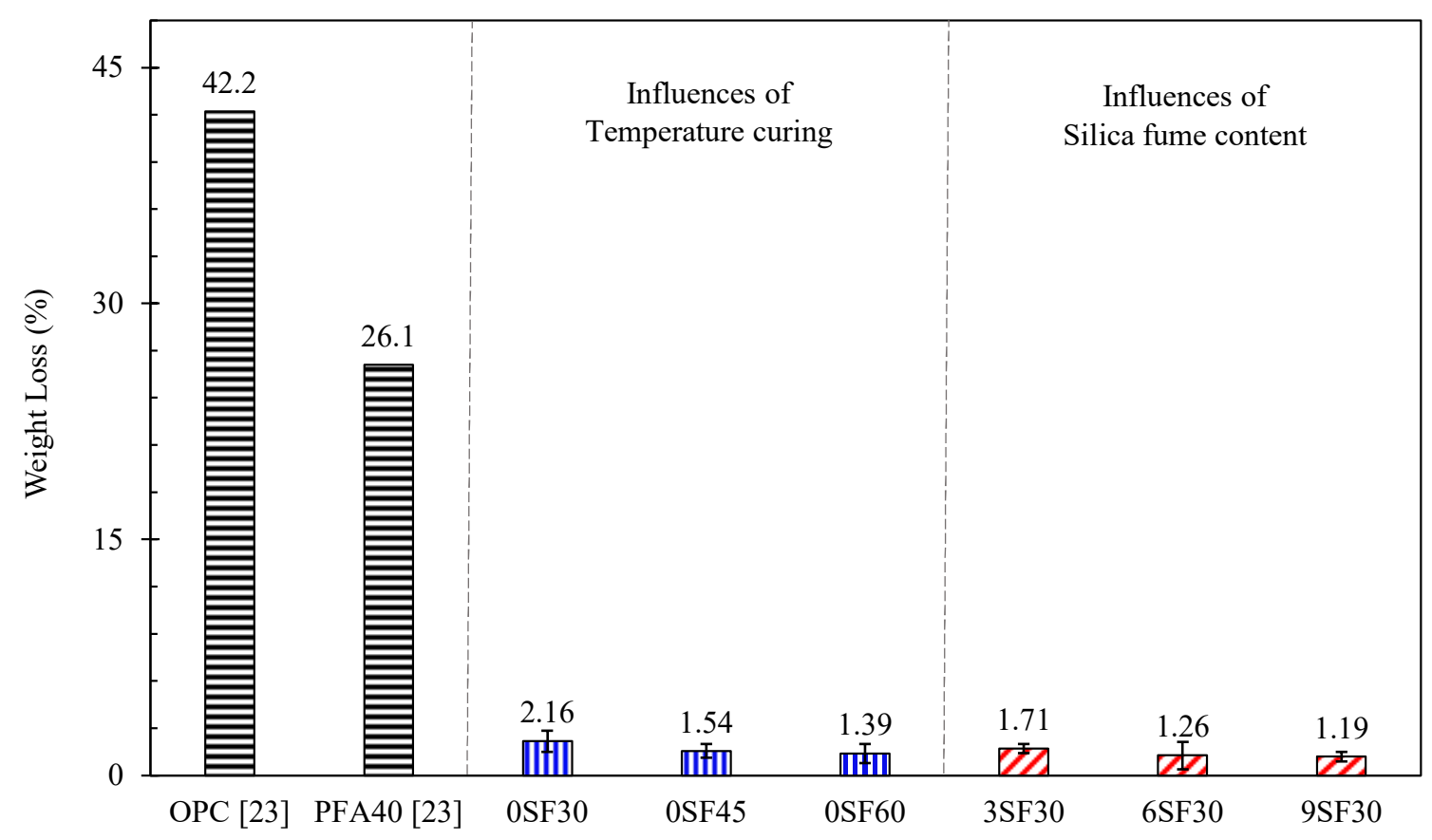

Figure 3. Weight loss of the alkali-activated mortar after 28 days of immersion in a $3 \%$ by weight sulfuric acid solution.

\subsection{Resistance to Sulfate Attacks}

\subsubsection{Magnesium Sulfate Resistance}

The loss of compressive strength data for alkali-activated mortars subjected to $5 \%$ magnesium sulfate $\left(\mathrm{MgSO}_{4}\right)$ solutions presented in Figure 4 show the effects of SF addition and curing temperature, respectively. Samples of alkali-activated mortars were immersed in a magnesium sulfate solution for 180 days and were tested to measure their compressive strength. Note that the magnesium sulfate solution reacted to the calcium hydroxide $\left(\mathrm{Ca}(\mathrm{OH})_{2}\right)$ and sodium hydroxide $(\mathrm{NaOH})$ solution, resulting in the production of magnesium hydroxide $\left(\mathrm{Mg}(\mathrm{OH})_{2}\right)$ and calcium sulfate $\left(\mathrm{CaSO}_{4}\right)$ compounds. Moreover, magnesium silicate hydrate and silica gel were also present in the alkali-activated mortars after the reaction between the magnesium sulfate solution and calcium-silicate-hydrate. The presence of these compounds caused a reduction in the alkali-activated mortar bonding, resulting in the loss of the compressive strength of the samples after immersion.

Figure 4 shows the results of the compressive strength tests for alkali-activated mortars with and without immersion in the magnesium sulfate solution for 180 days, labeled as "5\% of Magnesium sulfate" and "Room temp.", respectively. Clearly, the immersion of alkali-activated mortars in the magnesium sulfate solution significantly decreased the compressive strength. The highest compressive strength occurred when the alkali-activated mortars were cured at $60^{\circ} \mathrm{C}(0 \mathrm{SF} 60)$. Therefore, an increase in curing temperature increased the compressive strength. Note that the results labeled "OPC" in Figure 4 are for Portland cement (OPC) immersed in 5\% magnesium sulfate solutions and reported by Izquierdo et al. [52]. From Figure 4, the percentage strength loss between this study for the 0SF30 case and the OPC result of Izquierdo et al. [52] is not very different. 


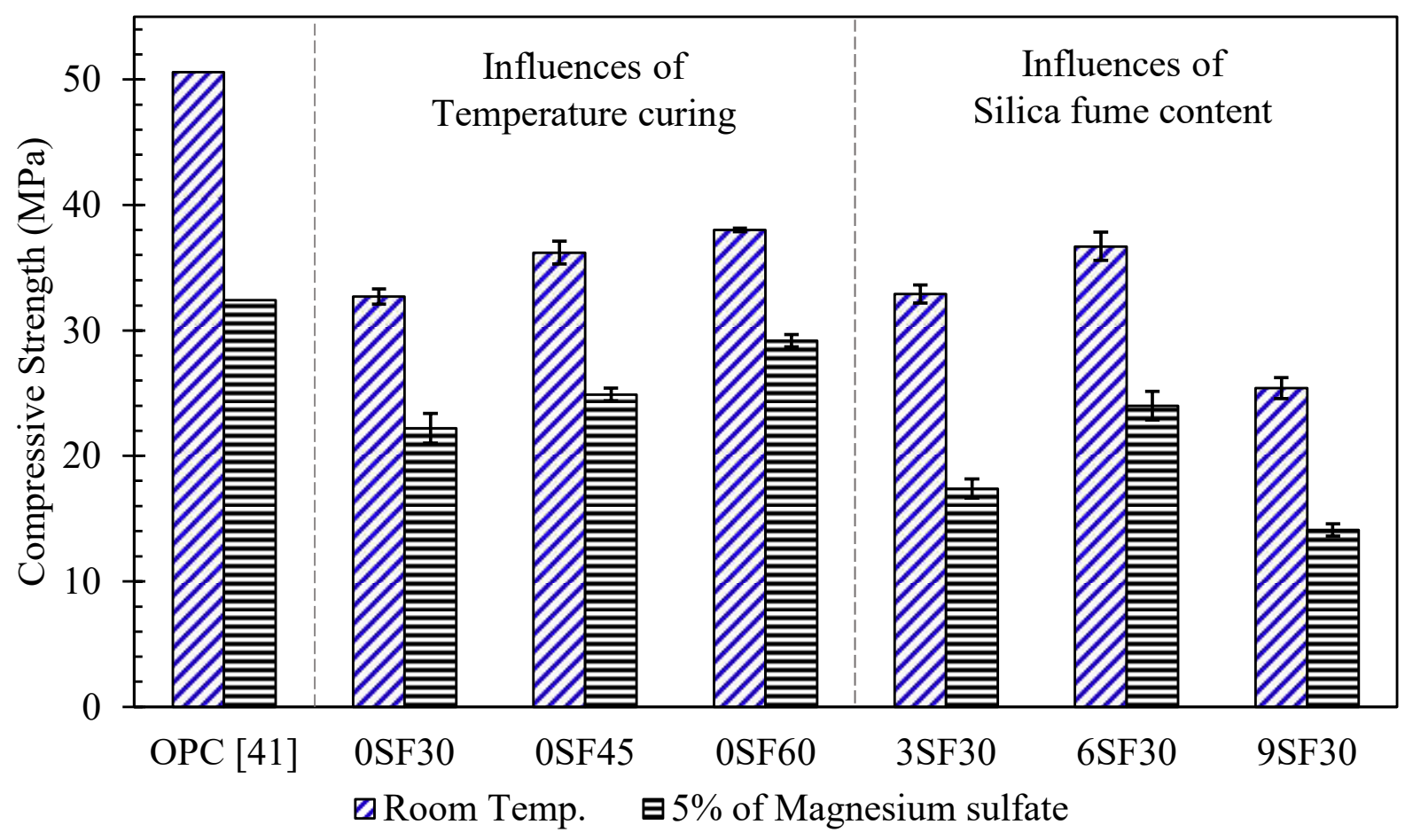

Figure 4. Compressive strength of the alkali-activated mortar after 180 days of immersion in a $5 \%$ by weight magnesium sulfate solution.

\subsubsection{Sodium Sulfate Resistance}

Figure 5 presents the relationship between the expansion due to $5 \%$ sodium sulfate solutions and the immersion time. Note that the results labeled "OPC" in Figure 5 were obtained for Portland cement (OPC) immersed in 5\% sodium sulfate solutions, as reported by Rodanan [53]. From Figure 5, the early-age expansions of immersed alkali-activated mortars were significantly larger than those of the OPC mortar before 3 days of immersion, because alkali-activated mortars have lower strengths compared to OPC mortars. The expansion rates of the alkali-activated and OPC mortars had nearly the same trend after 3 days of immersion.

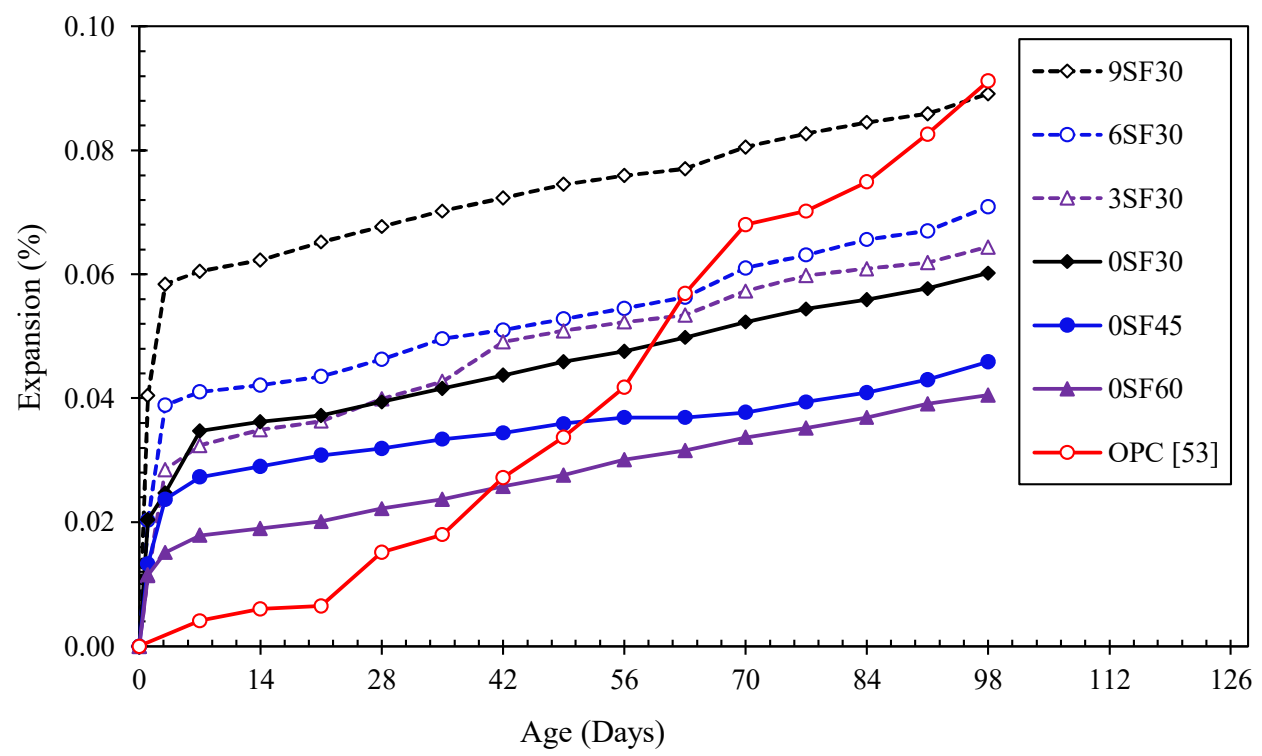

Figure 5. Relationships between the expansion of the alkali-activated mortar and age after 98 days of immersion in a $5 \%$ by weight sodium sulfate solution. 
From Figure 6, an increase in the percentage of SF caused an increase in the percentage of expansion. At 98 days of immersion, the expansion percentage of the alkali-activated mortar bars was $0.0394,0.0399,0.0463$, and 0.0677 for $0 \%, 3 \%, 6 \%$, and $9 \%$ SF, respectively. This behavior was because large amounts of SF cannot fully react in the geopolymerization process [54]. The excessive SF after the geopolymerization caused an increased number of pore gaps in the alkali-activated mortars [54]. These pore gaps allowed sodium sulfate solutions to infiltrate easily into samples and react with silica and alumina components, resulting in gypsum and ettringite formation [55]. As a result, the alkali-activated mortars with large SF percentages were more expansive than those with low SF percentages and the OPC mortars.

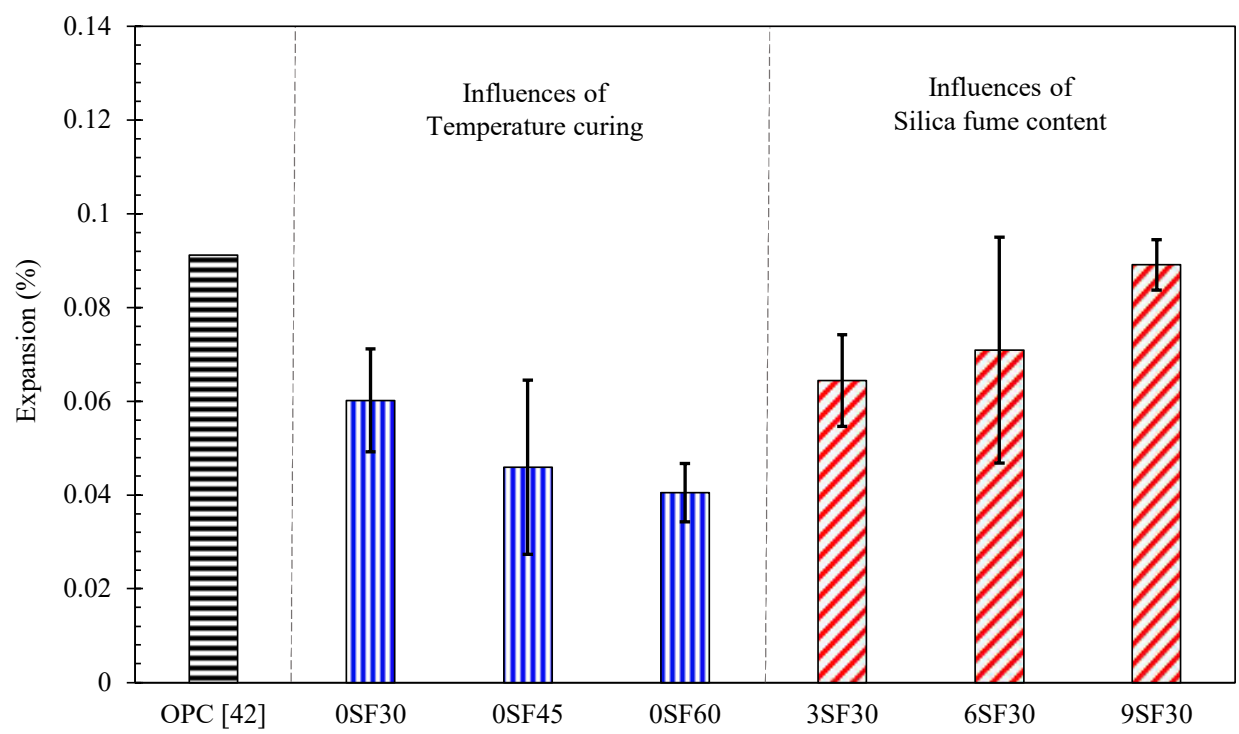

Figure 6. Expansion of the alkali-activated mortar after 98 days of immersion in a 5\% by weight sodium sulfate solution.

It is also interesting to note that after 98 days of immersion in a sodium sulfate solution, the alkali-activated mortar bars cured at $45^{\circ} \mathrm{C}$ and $60{ }^{\circ} \mathrm{C}$ had lower expansions than those cured at $30^{\circ} \mathrm{C}$ (room temperature). Note that the alkali-activated mortars cured at high temperatures had more aluminosilicate compounds than those cured at room temperature. These compounds significantly increased the resistance of mortars to a sodium sulfate attack [29]. Alkali-activated mortars, due to sodium sulfate attack with the increase of silica fume content, had expansion which increased rapidly in the early stages. Compared to OPC mortars, alkali-activated mortars were found to be less efficient. Still, alkali-activated mortars were more efficient over time because of the slower expansion rate of alkali-activated mortars.

\section{Conclusions}

This paper presents the properties of alkali-activated mortars with silica fume and curing at an ambient temperature. The effects of using silica fume to enhance properties of alkali-activated mortars were investigated, and the results were compared with alkali-activated mortars curing at an elevated temperature. These measurements included compressive strength, mass loss due to attack from $3 \%$ by weight sulfuric acid resistance, compressive strength loss due to a $5 \%$ by weight magnesium sulfate attack, and expansion due to a $5 \%$ by weight sodium sulfate attack. Based on these results presented in this paper, we could draw the following conclusions:

(1) The compressive strength of the alkali-activated mortar increased with extending the silica fume dosage. The optimum content of silica fume for use in alkali-activated mortars was $6 \%$, which had a compressive strength as high as an alkali-activated mortar without silica fume and cured at room temperatures of 45 and $60^{\circ} \mathrm{C}$. 
(2) The weight loss of the alkali-activated mortar due to a sulfuric acid attack decreased with increasing silica fume content and curing temperature. All alkali-activated mortars lost $2.16 \%$ or less of their weight 28 days after the acid attack, which was much less than for OPC mortars and mortars containing $40 \%$ of FA.

(3) The loss of compressive strength of the alkali-activated mortars immersed in magnesium sulfate solutions decreased with an increasing curing temperature.

(4) The expansion of the alkali-activated mortar due to the sodium sulfate attack increased with an increasing silica fume content and decreased with an increasing curing temperature. Compared with OPC mortars, all alkali-activated mortars were more vulnerable to attack by 5\% sodium sulfate at 1-35 days. After 98 days of immersion, all alkali-activated mortars had a better performance than the OPC mortars.

Author Contributions: Conceptualization, W.T.; Formal analysis, K.S. and W.D.; Investigation, K.S.; Methodology, W.T.; Visualization, S.K., C.T. and C.J.; Writing-original draft, W.D.; Writing-review \& editing, W.T., S.K. and C.T. All authors have read and agreed to the published version of the manuscript.

Funding: This research was supported by Thailand Science Research and Innovation (TSRI) under the Fundamental Fund 2022 (Project: Advanced Construction Towards Thailand 4.0) and Thammasat University Research Unit in Structural and Foundation Engineering, Thammasat University.

Institutional Review Board Statement: Not applicable.

Informed Consent Statement: Not applicable.

Data Availability Statement: The data presented in this study are available on request from the corresponding author.

Conflicts of Interest: The authors declare no conflict of interest.

\section{References}

1. Bosoaga, A.; Mašek, O.; Oakey, J.E. $\mathrm{CO}_{2}$ Capture Technologies for Cement Industry. Energy Procedia 2009, 1, 133-140. [CrossRef]

2. Zhang, M.; Lastra, R.; Malhotra, V. Rice-husk ash paste and concrete: Some aspects of hydration and the microstructure of the interfacial zone between the aggregate and paste. Cem. Concr. Res. 1996, 26, 963-977. [CrossRef]

3. Kiattikomol, K.; Jaturapitakkul, C.; Songpiriyakij, S.; Chutubtim, S. A study of ground coarse fly ashes with different finenesses from various sources as pozzolanic materials. Cem. Concr. Compos. 2001, 23, 335-343. [CrossRef]

4. Sata, V.; Jaturapitakkul, C.; Rattanashotinunt, C. Compressive Strength and Heat Evolution of Concretes Containing Palm Oil Fuel Ash. J. Mater. Civ. Eng. 2010, 22, 1033-1038. [CrossRef]

5. Wongkvanklom, A.; Posi, P.; Kampala, A.; Kaewngao, T.; Chindaprasirt, P. Beneficial utilization of recycled asphaltic concrete aggregate in high calcium fly ash geopolymer concrete. Case Stud. Constr. Mater. 2021, 15, e00615. [CrossRef]

6. Ibrahim, K. Recycled waste glass powder as a partial replacement of cement in concrete containing silica fume and fly ash. Case Stud. Constr. Mater. 2021, 15, e00630. [CrossRef]

7. Podolsky, Z.; Liu, J.; Dinh, H.; Doh, J.; Guerrieri, M.; Fragomeni, S. State of the art on the application of waste materials in geopolymer concrete. Case Stud. Constr. Mater. 2021, 15, e00637. [CrossRef]

8. Palomo, A.; Grutzeck, M.W.; Blanco, M.T. Alkali-activated fly ashes: A cement for the future. Cem. Concr. Res. 1999, 29, 1323-1329. [CrossRef]

9. Chindaprasirt, P.; Rattanasak, U.; Jaturapitakkul, C. Utilization of fly ash blends from pulverized coal and fluidized bed combustions in geopolymeric materials. Cem. Concr. Compos. 2011, 33, 55-60. [CrossRef]

10. Davidovits, J. Geopolymer: Inorganic polymeric new materials. J. Therm. Anal. 1991, 37, 1633-1656. [CrossRef]

11. Bakharev, T. Thermal behaviour of geopolymers prepared using class F fly ash and elevated temperature curing. Cem. Concr. Res. 2006, 36, 1134-1147. [CrossRef]

12. Kong, D.; Sanjayan, J. Damage behavior of geopolymer composites exposed to elevated temperatures. Cem. Concr. Compos. 2008, 30, 986-991. [CrossRef]

13. Kong, D.L.; Sanjayan, J.G. Effect of elevated temperatures on geopolymer paste, mortar and concrete. Cem. Concr. Res. 2010, 40, 334-339. [CrossRef]

14. Rickard, W.D.; van Riessen, A.; Walls, P. Thermal character of geopolymers synthesized from Class F fly ash containing high concentrations of iron and aquartz. Int. J. Appl. Ceram. Technol. 2010, 7, 81-88. [CrossRef]

15. Tayeh, B.A.; Zeyad, A.M.; Agwa, I.S.; Amin, M. Effect of elevated temperatures on mechanical properties of lightweight geo-polymer concrete. Case Stud. Constr. Mater. 2021, 15, e00673. 
16. Mohapatra, A.K.; Bera, D.K.; Rath, A.K. Effect of Silica Fume on Strength Enhancement of Geo-Polymer Mortar in Ambient Curing. In Lecture Notes in Civil Engineering; Springer: Singapore, 2021; Volume 75, pp. 819-830.

17. Janardhanan, T.; Venkatasubramani, V. Feasibility studies on compressive strength of ground coal ash geopolymer mortar. Period. Polytech. Civ. Eng. 2015, 59, 373.

18. Mehta, P.K. Sulfate attack on concrete: A critical review. In Concrete Durability; Villarreal, R.R., Ed.; University Autonoma de Nuevo Leon: Leon, Mexico, 1993; pp. 107-132.

19. Wakely, L.D.; Poole, T.S.; Ernzen, J.J.; Neeley, D.B. Salt saturated mass concrete under chemical attack. In High Performance Concrete in Severe Environments; Zia, P., Ed.; American Concrete Institute: Farmington Hills, MI, USA, 1993; Volume SP-140, pp. $239-267$.

20. Irassar, E.; Di Maio, A.; Batic, O. Sulfate attack on concrete with mineral admixtures. Cem. Concr. Res. 1996, 26, 113-123. [CrossRef]

21. Ferraris, C.F.; Clifton, J.R.; Stutzman, P.E.; Garbocsi, E.J. Mechanisms of degradation of Portland cement-based systems by sul-fate attack. In Mechanisms of Chemical Degradation of Cement-Based Systems; Scrivener, K.L., Young, J.F., Eds.; E and FN Spon: London, UK, 1997; pp. 185-192.

22. Santhanam, M.; Cohen, M.D.; Olek, J. Mechanism of sulfate attack: A fresh look: Part 2. Proposed mechanisms. Cem. Concr. Res. 2003, 33, 341-346. [CrossRef]

23. Taylor, H.F.W.; Gollop, R.S. Some chemical and microstructural aspects of concrete durability. In Mechanisms of Chemical Degradation of Cement-Based Systems; Scrivener, K.L., Young, J.F., Eds.; E and FN Spon: London, UK, 1997; pp. 177-184.

24. Bonen, D.; Cohen, M. Magnesium sulfate attack on Portland cement paste: I. Microstructural analysis. Cem. Concr. Res. 1992, 22, 169-180. [CrossRef]

25. Bonen, D.; Cohen, M. Magnesium sulfate attack on Portland cement paste: II. Chemical and mineralogical analyses. Cem. Concr. Res. 1992, 22, 707-718. [CrossRef]

26. Davidovits, J. Properties of geopolymer cements. In Proceedings of first International Conference on Alkaline Cements and Concretes; Kiev, Ukraine, 11-14 October 1994, SRIBM: Kiev, Ukraine, 1994; Volume 1, pp. 131-149.

27. Temuujin, J.; Minjigmaa, A.; Lee, M.; Chen-Tan, N.; van Riessen, A. Characterisation of class F fly ash geopolymer pastes immersed in acid and alkaline solutions. Cem. Concr. Compos. 2011, 33, 1086-1091. [CrossRef]

28. Chindaprasirt, P.; Chareerat, T.; Sirivivatnanon, V. Workability and strength of coarse high calcium fly ash geopolymer. Cem. Concr. Compos. 2007, 29, 224-229. [CrossRef]

29. Bakharev, T. Durability of geopolymer materials in sodium and magnesium sulfate solutions. Cem. Concr. Res. 2005, 35, 1233-1246. [CrossRef]

30. Van Jaarsveld, J.; Van Deventer, J.; Lorenzen, L. The potential use of geopolymeric materials to immobilise toxic metals: Part, I. Theory and applications. Miner. Eng. 1997, 10, 659-669. [CrossRef]

31. Davidovits, J. Geopolymer, green chemistry and sustainable development solutions. In Proceedings of the World Congress Geopolymer 2005; Geopolymer Institute: Aisne, France, 2005.

32. Bakharev, T. Resistance of geopolymer materials to acid attack. Cem. Concr. Res. 2005, 35, 658-670. [CrossRef]

33. Sata, V.; Sathonsaowaphak, A.; Chindaprasirt, P. Resistance of lignite bottom ash geopolymer mortar to sulfate and sulfuric acid attack. Cem. Concr. Compos. 2012, 34, 700-708. [CrossRef]

34. Ariffin, M.; Bhutta, M.; Hussin, M.; Tahir, M.M.; Aziah, N. Sulfuric acid resistance of blended ash geopolymer concrete. Constr Build. Mater. 2013, 43, 80-86. [CrossRef]

35. Duan, P.; Yan, C.; Zhou, W.; Luo, W.; Shen, C. An investigation of the microstructure and durability of a fluidized bed fly ash-metakaolin geopolymer after heat and acid exposure. Mater. Des. 2015, 74, 125-137. [CrossRef]

36. Pereira, A.; Akasaki, J.L.; Melges, J.L.P.; Tashima, M.M.; Soriano, L.; Borrachero, M.V.; Monzó, J.; Payá, J. Mechanical and durability properties of alkali-activated mortar based on sugarcane bagasse ash and blast furnace slag. Ceram. Int. 2015, 41, 13012-13024. [CrossRef]

37. Rao, G.M.; Kireety, C.H. Durability Studies on Alkali Activated Fly Ash and GGBS-Based Geopolymer Mortars. In Sustainable Construction and Building Materials; (Lecture Notes in Civil Engineering); Das, B.B., Neithalath, N., Eds.; Springer: Singapore, 2019; Volume 25, pp. 85-97.

38. Li, Z.; Peethamparan, S. Leaching resistance of alkali-activated slag and fly ash mortars exposed to organic acid. Green Mater. 2018, 6, 117-130. [CrossRef]

39. ElYamany, H.E.; Elmoaty, A.E.M.A.; Diab, A.R.A. Sulphuric Acid Resistance of Slag Geopolymer Concrete Modified with Fly Ash and Silica Fume. Iran. J. Sci. Technol. Trans. Civ. Eng. 2020, 45, 2297-2315. [CrossRef]

40. Allahverdi, A.; Skvara, F. Sulfuric acid attack on hardened paste of geopolymer cements-Part 1. Mechanism of corrosion at relatively high concentrations. Ceram. Silik. 2005, 49, 225.

41. Allahverdi, A.; Skvara, F. Sulfuric acid attack on hardened paste of geopolymer cements-part 2. Corrosion mechanism at mild and relatively low concentrations. Ceram. Silik. 2006, 50, 1.

42. Thokchom, S.; Ghosh, P.; Ghosh, S. Resistance of fly ash based geopolymer mortars in sulfuric acid. ArPN J. Eng. Appl. Sci. 2009, $4,65-70$.

43. SWallah, E.; Rangan, B.V. Low-calcium fly ash-based geopolymer concrete: Long-term properties. In Res Rep.-GC2; Curtin University Australia: Bentley, Australia, 2006; pp. 76-80.

44. Valencia-Saavedra, W.G.; de Gutiérrez, R.M.; Puertas, F. Performance of FA-based geopolymer concretes exposed to acetic and sulfuric acids. Constr. Build. Mater. 2020, 257, 119503. [CrossRef] 
45. American Society for Testing and Materials (ASTM) C230; Standard Specification for Flow Table for Use in Tests of Hydraulic Cement. ASTM International: West Conshohocken, PY, USA, 2014.

46. American Society for Testing and Materials (ASTM) C109-16; Standard Test Method for Compressive Strength of Hydraulic Cement Mortars (Using 2-In. Or [50 mm] Cube Specimens). ASTM International: West Conshohocken, PY, USA, 2016.

47. American Society for Testing and Materials (ASTM) C267; Standard Test Methods for Chemical Resistance of Mortars, Grouts, and Monolithic Surfacings and Polymer Concretes. ASTM International: West Conshohocken, PY, USA, 2003.

48. American Society for Testing and Materials (ASTM) C1012; Standard Test Method for Length Change of Hydraulic-Cement Mortars Exposed to a Sulfate Solution. ASTM International: West Conshohocken, PY, USA, 2018.

49. Prabha, V.; Revathi, V. Geopolymer Mortar Incorporating High Calcium Fly Ash and Silica Fume. Arch. Civ. Eng. 2019, 65, 3-16. [CrossRef]

50. Das, S.K.; Mustakim, S.M.; Adesina, A.; Mishra, J.; Alomayri, T.S.; Assaedi, H.S.; Kaze, C.R. Fresh, strength and microstructure properties of geopolymer concrete incorporating lime and silica fume as replacement of fly ash. J. Build. Eng. 2020, 32, 101780. [CrossRef]

51. Aydın, S.; Yazici, H.; Yiğiter, H.; Baradan, B. Sulfuric acid resistance of high-volume fly ash concrete. Build. Environ. 2007, 42, 717-721. [CrossRef]

52. Izquierdo, S.; Diaz, J.; Mejía De Gutiérrez, R.; Torres, J. Durability of FCC-blended mortar exposed to sodium and magnesium sulfate. Rev. Ing. Constr. 2016, 31, 183-190. [CrossRef]

53. Rodanan, A. Durability of Cement Mortar Containing Black Rice Husk Ash under Sodium Sulfate and Magnesium Sulfate Attack. Master's Thesis, Thammasat University, Bangkok, Thailland, 2004.

54. Chindaprasirt, P.; Paisitsrisawat, P.; Rattanasak, U. Strength and resistance to sulfate and sulfuric acid of ground fluidized bed combustion fly ash-silica fume alkali-activated composite. Adv. Powder Technol. 2014, 25, 1087-1093. [CrossRef]

55. Clark, B.A.; Brown, P.W. Formation of Ettringite from Monosubstituted Calcium Sulfoaluminate Hydrate and Gypsum. J. Am. Ceram. Soc. 2004, 82, 2900-2905. [CrossRef] 